\title{
Iowa's Planning Programs of the Past and Present
}

\section{George Mills}

FOUR MAJOR GROUPS HAVE presented extensive planning programs in the last forty years on how to improve Iowa, its life and its economy. Often the plans worked out well. But inevitably there were some misjudgments and failures to reach goals.

These past programs are being scrutinized now that attention is centering once again on large-scale planning for Iowa. A new task force has embarked on a statewide study looking ahead to Iowa up to the year 2000. The result will be another set of recommendations for bettering the lives of Iowans and their pursuits in the next twenty-five years.

Every Iowa planning venture has been launched in a glowing atmosphere of hopes and expectations. Even in the Depression, after tens of thousands of Iowans had lost their land and/or their jobs and homes, the Iowa State Planning Board said in 1934:

The board envisions a commonwealth where health, happiness, thrift and prosperity prevail, with all the people living in homes that are sanitary, convenient, attractive and durable. It further envisions its cities and its countrysides without ugliness or untidiness, and no unnecessary waste of land, water or forest resources.

The "Iowa 2000" committee has warned that gaining industry and jobs can be offset by increased pollution, congestion, rising taxes and so on. How to gain the advantages of industrial expansion and avoid the drawbacks is the problem. "We share a grand challenge," said the committee, and Iowa is "a grand place in which to meet it."

The four principal Iowa planning organizations prior to 
"Iowa 2000" were: the Iowa Twenty-Five Year Conservation Plan of 1933; the Iowa State Planning Board of 1934-1939; the Iowa Postwar Rehabilitation Commission of 1944, and the 1958 Governor's Committee of One Hundred on Iowa's Economic and Social Trends.

$$
\text { \# \# }
$$

In the 1930s Iowa was interested in acquiring large national and state forests. The plight of depression-ridden agriculture was one main reason for this. Commodity prices sank to disastrous levels—corn as low as ten and fifteen cents a bushel, hogs $\$ 3$ per 100 pounds. Property taxes went unpaid on as much as forty-nine per cent of the land in some townships. Insurance companies and other big lenders had to foreclose on many thousands of farm mortgages. Before the tide turned, large corporations unwillingly owned foreclosed land equivalent in area to farms in eleven of the state's ninety-nine counties.

The twenty-five-year conservation plan stated in 1933: "It is quite likely that agriculture in Iowa would profit as a whole if all the $2^{1 / 2}$ million acres of cut-over land were reforested, and that much pasture and crop land removed from competition." Two years later, the planning board agreed with the reforestation idea. The board listed 1.7 million acres of Iowa land as suitable for sites of national forests, and another 290,000 acres believed available for purchase as state forests. There was a three-fold purpose in the forestry plan: to reduce crop surpluses by taking land out of production; to stop soil erosion (which trees do) and to grow a profitable timber crop on almost worthless land. Iowa experts said a yield of as much as 35,000 board-feet of timber could be harvested per acre in thirty-five years time. ${ }^{1}$

The federal government did start buying Iowa land for forests in the mid-1930s but ceased after acquiring only 4,649 acres in four counties-2,572 in Lee, 1,130 in Appanoose, 646 in Davis and 300 in Van Buren. The price paid averaged about $\$ 9$ an acre. Prices of other tracts were too high, and the national forest movement came to a halt.

The Iowa Conservation Commission bought the 4,649 acres from the government in the 1960s. The tracts were added to state

${ }^{1}$ A board-foot is a piece of wood one foot square and one inch thick. 
forests which now total some 23,000 acres. The state purchase program did not get very far in the 1930 s either. The present state forest total does not include such areas as state parks and refuges. All this is not to say that Iowa is nearly bereft of woodlands. A 1933 estimate placed the overall area of the state in timber at close to two million acres, much of that in woodlots on farms and sometimes along rivers and streams. But that total was far less than the five million acres in woods when the first settlers arrived back in the 19th century. They cleared large areas for cultivaton of crops. The federal and state program was designed to return some of those cleared areas to timber.

$$
\text { \# \# }
$$

The federal farm programs of the New Deal era began to take hold in 1934-1935. Those programs sought to lessen the burdensome crop surpluses by removing land from production. The planning board evidently went along. The board suggested that Iowa farmers cut their corn acreage seven per cent, and small grain acreage four per cent, but boost the acreage of soil-conserving hay by nine per cent.

A great worry of the 1930s was the large amount of Iowa land farmed by tenants. They cultivated nearly six out of every ten farm acres in the state, 58.9 per cent to be exact. Owners farmed the other 41.1 per cent. ${ }^{2}$

Farm tenants usually were too poor to buy land. They also often lived an unstable life. Leases ran only from year to year and the renter and his family often had to move. Tenants thus often did not become part of a community. They were less likely to support schools and churches. They worked the land hard in most instances and thereby increased losses due to erosion. Said the board: "There is evidence that these farms have already become depleted of soil fertility as shown by their lower yields." The board wanted tenants to be able to buy farms. Best hope for obtaining the necessary financing appeared to be federal credit agencies, and quite a few farms were bought via that method in

${ }^{2}$ Renters operated $20,250,000$ acres in Iowa, and owners $14,117,000$ acres. In 1935 the planning board commented, "This condition gives rise to serious problems of soil conservation and the protection of a group of people (tenants) who comprise over 40 per cent of the rural population of the state." 
the succeeding years. Also, the board urged insurance companies and other lenders "to adopt a more liberal sales policy" in disposing of the huge amounts of land they had acquired by mortgage foreclosures. In one way and another these corporations did sell that land rapidly, especially after 1939 .

To further ease the situation for renters it was strongly recommended by the board, and others, that land leases be extended beyond the usual year lease and that lower rentals be established to enable tenants to practice soil conservation measures.

The tenancy situation was not discussed much in Iowa during the 1960s and 1970s. For one thing, the share of Iowa land owned by operators had increased from 41.1 per cent in 1934 to 52.8 per cent in 1970 , rising from $14,117,000$ acres to $17,780,000$ acres. The renter's share dropped from the $20,250,000$ acres to $15,909,000$ or from 58.9 per cent to 47.2 per cent. A substantial portion of today's rented land is leased by nearby owners who wish to farm additional acres. Tenancy has ceased to be a troublesome problem.

$$
\text { \# \# }
$$

A warning issued by the Iowa Postwar Rehabilitation Commission in 1944 is especially interesting now, in light of the astounding increases in prices of Iowa land in recent years. ${ }^{3}$ Many members of the 1944 commission knew from first-hand experience the effects of the sharp rise, and subsequent disastrous collapse, in land prices in the 1920s and 1930s. They wanted to avoid a similiar price fluctuation after World War II. " "One of the greatest dangers facing Iowa is the possibility of inflation of land values," the commission said. "Trouble will be upon us if speculation for quick profits becomes common. . . It eventually breaks most of the speculators and often defrauds the bona fide purchasers."

${ }^{3}$ The post-war commission reports are contained in two paper-covered volumes, one 102 pages and the other 121 pages. They present interesting views of Iowa life and problems during the post-war era of three decades ago. The commission consisted of twenty-five Iowans appointed by Governor Bourke Hickenlooper. Rodney Q. Selby, later development commission chief, served as executive director. P. H. Elwood, head of the architecture department at Iowa State University in Ames, was the chief commission adviser. Elwood also had been director-consultant of the State planning board in the 1930s.

${ }^{4}$ It was recalled how land prices rose in 1919 and 1920 to an average of around $\$ 250$ an acre, then sank in the following years to a low of $\$ 65$ in 1933. 
The commission expressed belief that there would be no boomand-bust psychology in Iowa after World War II, and there wasn't really. Iowa land averaged $\$ 105$ an acre in 1944 and rose only to $\$ 138$ by 1947 and $\$ 153$ in 1948 . Where the boom has come is in the last ten years. Federal estimates show Iowa land was valued at $\$ 256$ an acre in 1963 , then zoomed to $\$ 418$ an acre by 1972 , to $\$ 482$ in 1973 , and to over $\$ 700$ an acre in 1975 ! Those figures would have left the 1944 commission breathless.

Life in Iowa certainly is far more enjoyable as well as cleaner now than in the 1930s, and the planners deserve a share of the credit for the improvement.

Untreated sewage from more than 100 Iowa cities and towns was contaminating Iowa streams and lakes in the 1930s. Watering cattle in lakes and streams added to the problem. So did the flow of "barnyard wash" into such waters. Taking the lead in publicly attacking such situations was the twenty-five-year plan, a brain-child of J. N. (Ding) Darling, Des Moines Register cartoonist. "Enormous damage has been done to the surface waters in the brief period of the white man's life here," the plan said. "Sewage pollution at some points has far over-reached the legitimate use of rivers for dilution. . . Nearly every town in Iowa must eventually purify its sewage, either partially or completely." This idea sounds most reasonable now but was difficult to put across in 1933. The fact was that over fifty per cent of urban Iowans in 1935 lived in municipalities lacking sewage treatment plants.

The state health department, long unhappy over the filth in the streams, was glad to have the planners call attention to the situation. The drive got results.

Using federal money and workers from the unemployment rolls, Iowa authorities completed considerable treatment plant construction before World War II broke out in 1941. But by 1944 there were still seventy-two cities and towns with a combined population of 413,000 that lacked plants. The situation was rectified considerably in succeeding years, although the task of building new plants and updating old ones is never-ending.

The twenty-five year plan also called attention to the following:

Drainage has witlessly destroyed some wonderful lakes and marshes now proven of no use to agriculture ... Erosion has been tremendously accelerated by breaking the prairie sod and cutting off the 
woods ... Silting in waters has been correspondingly accelerated to a serious degree . . . Private ownership of adjoining lands has cut off public access from... lakes and rivers.

The plan recommended: "Restorations for some twenty lakes and marshes that have been unwisely drained, the eventual construction of perhaps thirty artificial lakes, various improvements at seventy-five existing lakes and marshes ... . and provision for public access at 250 points alongside streams and lakes."

The program further called for aiding migratory waterfowl, such upland game birds as pheasants and quail, development of trout streams and other fish streams, fish hatcheries, establishment of preserves, designation of seventeen state parks, all within a two-hour drive over good roads "from any home in the state."

With at least 66,000 Iowa families on the relief rolls in the Depression, various projects on the twenty-five-year plan list meant welcome jobs for a lot of unemployed men. Praising the twentyfive-year plan, the state planning board in 1934 said: "No time was lost in getting construction under way. In one year, some phases of the twenty-five-year program had been advanced to a degree equivalent to 10 years of normal growth and development. This experience is a practical demonstration that it pays to plan.' " W. C. Brabham, now assistant state conservation director, said: "This was the first time Iowans were shown that planning really works. Lake Wapello in Davis County is a shining example. Plans for that artificial lake and the state park, 1,143 acres all told, were all ready to go when the opportunity presented itself." 5

How does Iowa stand in the various conservation fields now? Said Brabham: "I think the Iowa erosion control program is the best I've seen in any state . . . Our fish hatcheries have gone far beyond what they anticipated in the way of production in 1933. We've got more fish than ever. Iowa leads the nation in the harvesting of pheasants. And we have more deer now than we had 100 years ago."

Considerable restoration of water areas has been achieved, Brabham added, citing Rice Lake in Winnebago-Worth Counties

${ }^{5}$ The Civilian Conservation Corps (CCC), a federal conservation program employing jobless young men, provided much of the labor for the Lake Wapello project. 
and Goose Lake in Green County as examples. Regarding cleaning up the streams, he asserted,

We've made a lot of progress. One example is the west fork of the Des Moines River south of Estherville. The sewage from the packing plant caused the water to run red at one time. There were no fish, nothing but problems. The stench was so bad you couldn't stand it. They put in a new sewage treatment plant. Now you can catch wall-eyes in that same place.

Some of the 1933 recommendations did not work out, of course-such as the proposed vast increase in forests and the dredging of silt from the lakes. Also, the state maintains no refuges for upland game birds, such as pheasants and quail, or for deer. Research showed that none was needed, Brabham said. Nor are there refuges for prairie chickens or beaver. "I can't remember when the last prairie chicken was seen in Iowa." he added. "As for beaver, the beaver and the farmer with a drainage ditch don't see eye to eye." He said the twenty-five-year plan needs updating "but the basic stuff is there. It was one of the greatest blueprints for conservation ever prepared," he observed. "It is still valuable even though it was put together more than forty years ago."

One big worry of the planners in the 1930 s was the number of Iowans moving outside the state. The planning board said in 1935 that an average of 250,000 people left Iowa every ten years in each of the preceding three decades. Between 1925 and 1935, Iowa lost between eleven per cent and thirty per cent annually of those from twenty-five to thirty-four years old, called the "prime of life" group. That is why the planners wanted life made "more pleasant" in this state. "Community councils, working with county and statewide councils, must develop a wider social life in every community," the 1935 report said. "Community center buildings must be constructed and used extensively ... A tangible example of the possibilities and advantages of a social and leisuretime program must be produced and followed."

Whether these ideas had any real effect on the outward flow of people to other states is doubtful. Iowa's population has risen only to 2.8 million compared with 2.2 million back in 1900 . The nation's population meanwhile has almost tripled, rising from 76 million in 1900 to 211 million in 1974.

The reason for Iowa's slow growth over the years was the de- 
cline in the farm population; mechanization and other efficiencies have reduced the need for workers in agriculture. Without such losses, the state's population would have risen sharply due to the excess of births over deaths, and gains in cities.

It is important to have in planning some idea how large the population of the state is going to be in future years. Iowa planners have made some fairly good guesses. In the 1930s they estimated the figure would be between 2.5 million and 3 million by 1980 , which is the correct range. They made what probably is another good guess in 1934 when they predicted the Iowa birth rate in 1980 will be approximately 66 births per 1,000 women between 15 and 45 years of age. The rate was 124.5 per 1,000 in 1960 and had dropped to 87.3 in 1970 . The figure of 66 per 1,000 "could be close by 1980 ," a state statistician said recently.

Iowa hopes soared for a time in the dark days of the Depression. Planning board figures in 1934 indicated that population losses had been reversed. Population gains were considered a sign of progress in those days. "It seems more than likely that Iowa's population is increasing at the present time through migration," the report said. "Young people, many of whom have migrated to out-of-state cities, have returned. Meanwhile, the normal movement from farm to city has not resumed."

In fact, the report said, farm families were moving into Iowa, particularly in the Northwest and Central parts of the state. Some seventy-four farm families had entered Iowa, nearly all from the Dakotas. They settled in Story, Boone, Cherokee, Sioux and Woodbury Counties. At the same time, only eighteen farm famlies moved out of those areas. "If the present inter-change continues, fifteen Northwest Iowa counties will gain between 700 and 1,000 farm families between 1934 and 1936," the board said. Alas! Those gains were temporary at best. The downward trend of the rural population resumed (if it had ever stopped) and has continued uninterruptedly ever since.

One marked characteristic of the Depression was the drop in the number of children born in Iowa. Births declined from 51,305 in 1923 to 39,575 in 1933 , a reduction of more than 20 per cent. Planners in 1934 foresaw a drop in school enrollments but added hopefully that that "may be balanced by the greater need for adult education." Unknown to the planners were the forthcoming 
spectacular increases, and equally spectacular declines, in birth rates in the next forty years.

By 1946 , only a dozen years later, Iowa births totaled 55.743 , a rise of more than forty per cent, and in 1951 the figure reached a record 66,123 . And in the 1960 s the "birth control" pill came into prominence. Now Iowa births are back down to 40,000 a year, again drastically affecting school planning.

Where the planners of the 1930s probably look best is in what they proposed for Iowa schools. The planning board in 1935 urged that steps be taken to drastically reduce the number of oneroom "little red schoolhouses" in Iowa. There were 9,215 elementary one-room rural schools in the state then. There are none now. The planners also said Iowans would get more for their school tax dollars if small school districts were merged into larger units. There are only 452 now.; some of them countywide in size.

In those days, property taxes provided practically all the money used in operating schools. State aid to schools totaled less than $\$ 500,000$ a year well into the 1940 s. Planning authorities recommended that the state take over much of the burden by "guaranteeing a minimum educational program" for every child. in the state. In other words, that every child be given the same quality schooling whether he lived in a rich or poor district. Out of this has come the large state school aid program that exceeds $\$ 250$ million a year now.

The planners also wanted teachers to be required to have at least two years of college. (Some had had no college at all in those days.) The law now requires every teacher to have a four-year degree as a beginning minimum.

$$
\text { \# \# }
$$

No individual board could possibly have done the enormous amount of work represented in the twenty-five-year conservation plan and the planning board reports of the 1930s. Both had the expert assistance of large numbers of highly qualified technicians.

The twenty-five-year plan was an outgrowth of work jointly directed by the old state board of conservation, headed by Mrs. Henry Frankel of Des Moines, and the old fish and game commission, of which Dr. W. C. Boone of Ottumwa was chairman. Information and recommendations were gathered from more than 
1;000 Iowans and others in various fields. "Probably never before in America has so varied and skilled an assembly of talent been set to work on a co-ordinated conservation planning project,"' the twenty-five-year report noted. The experts included biologists, geologists, biochemists, foresters, agronomists, landscape architects, game experts, fishery experts, hydrologists, sanitarians, economists, county agents and engineers, game wardens and many others.

The conservation survey involved more than 40,000 miles of travel, by motor vehicle and airplane, distribution of 1,200 questionnaires to knowledgable Iowans and the examination of 2,000 locations in the state for intelligence on conservation problems. The survey took eighteen months.

Publication of the conservation report in a bound volume of 177 pages of high quality paper was paid for personally by J. N. (Ding) Darling, the Register's cartoonist.

The two large planning board volumes, one 507 pages and the other 226 pages, were paid for out of federal funds. The unpaid planning board was headed by $\mathrm{H}$. $\mathrm{H}$. Kildee, dean of agriculture at Iowa'State University. There were forty-one state planning boards in the nation and they all reported to the National Resources Board headed by Harold L. Ickes, then secretary of the Interior:

Working for the planning board at its peak were $150 \mathrm{em}$ ployees, and upwards of 175 technical advisers collected information and provided recommendations. The special board committees, the co-ordinators and the technical advisers all were blueribbon Iowans of their times.

Dean Kildee tried to get the planning board declared a permanent state government agency. The 1937 Legislature gave the board official status but the 1939 Legislature let the board die. The Republicans had returned to power in Iowa as a result of the 1938 elections. Federal spending had lost a lot of its glamor and so had the New Deal government of President Franklin Roosevelt. The G.O.P. wanted no part of continuing indefinitely a state board of Democratic federal parentage.

$$
\text { \# \# }
$$

After World War II, the Iowa Postwar Rehabilitation Commission; Don Berry of Indianola chairman, had great impact in 
bringing to.light all the deferred needs that had been postponed by the Depression and by World War II. "Buildings on Iowa farms are generally in a poor state of repair," said the report, and so were many in cities and towns. That meant a lot of work for the construction industry. Half the farm houses still were without electricity.

Municipalities needed waterworks, sewage plants and other buildings. County projects were piled up. There was plenty left to do from the twenty-five-year conservation plan and the planning board reports. Conservation authorities were talking about 50 artificial lakes and 10 new state parks, among other things. Railroads, retail establishments; businesses generally told of plans to increase employment.

Some 20,000 workers from Iowa factories went into the armed forces. The factories reported that their employment had risen from 72,000 in pre-war 1940 to 93,000 in 1944. But that figure was expected to drop to 90,000 after the war. Factory officials expected no unemployment problem for two reasons: Many thousand aged male employees planned to retire, and as many as 8,000 females were expected to quit their jobs and stay home. "It is clearly apparent that every returning serviceman who wants his job back will get it."

Iowa industry since has expanded far beyond the dreams of the planners of thirty years ago. Industrial employment in the state now is close to 250,000 , or more than two and a half times above the figure of thirty years ago. Much of that new employment has risen from large industrial corporations expanding throughout the nation. The Alcoa plant which was located near Davenport in 1947 is a prime example. The commission said of such decentralizations: "These indeed are our new frontiers." Much of the Iowa increase also came from major expansion of existing industry, of which John Deere is another example. And a number of new packing plants have been opened in the state, more than offsetting in business volume those which have ceased operations.

$$
\text { \# \# }
$$

"We feel that the economic and social development of lowa has lagged" Howard Bowen said in 1958. "Our state has lacked dynamism. We believe that our major weaknesses are a lack of effective 
machinery for long-range planning and a lack of effective organization for state-wide leadership." A "wholesale overhaul" of state and local government was essential to overcome these deficiencies, Bowen added. His comments attracted wide attention because he was chairman of the Governor's Commission on Economic and Social Trends.

Governor Herschel Loveless appointed the 100 -member commission in 1957 to study the future of Iowa. Bowen was president of Grinnell College at the time, and later became president of the University of Iowa. Of the four Iowa groups that delved into the state's future in the quarter century between 1933 and 1958, the Bowen commission was the most sharply critical.

"Government institutions and procedures in Iowa are clearly outdated and are grossly inadequate for the tasks that lie ahead," the commission reported. The foremost problem, the commission added, was the lack of a state planning office responsible to the governor. Such an office could "formulate and co-ordinate longrange programs for state advancement in all fields, including reorganization of state and local governments, economic and industrial development, and improvement of communities and their services."

The Office of Planning and Programming (OPP) was established under Governor Robert Ray in 1969. The OPP pretty much possesses the planning power recommended by the Bowen commission.

Many of the commission's suggestions since have been enacted into law and many have not. One major step has been reapportioning the Legislature fairly according to population. The Legislature had been under the control of rural counties with less than thirty per cent of the state's population. The inbalance was corrected, thanks to rulings of the U.S. Supreme Court.

The commission called for major reform of the courts of the state, which has been accomplished. Among the other recommendations that since have been approved are the following: State scholarships for needy students; civil service system for state employees; home rule for cities and towns; more rapid school district reorganization and a "substantial" increase in state aid to schools; use of federal funds for public housing; annual sessions of the Legislature; credit for new and expanding enterprises; item veto power for the governor; a shift in emphasis in rural high 
schools from vocational agriculture to basic education; encouragement for joint areawide planning; emphasis on study of agricultural marketing; revision of "archaic" safety laws; higher workmen's and unemployment compensation payments.

The commission recommended, as did its predecessors, creation of a state Department of Transportation, a goal that was achieved during the 1974 Legislature. The commission also asked that the Highway Commission be given power to spend more road money on roads carrying the heaviest traffic, and to withdraw money from roads where traffic has declined. Rural forces never would agree to such a step, and it has not been taken. Nor has a bipartisan commission ever been named to study revision of the state Constitution.

The Bowen commission asked that only the governor and lieutenant governor be elected and the other presently elective officials be appointed. This has never come to be, although terms of office have been lengthened from two years to four years, as recommended. But the terms of state representatives have not been increased from two years to four years.

The commission further suggested that County Supervisors be given the power to appoint most of the presently-elective other County officials. That recommendation was ignored, as was another to authorize unified city-county governments. The commission said that tax dollars were wasted, service suffered and there was a substantial loss of time and effort in the operation of local governments. "There is no significant machinery, with the single exception of the consolidated school district, for integrating the government of towns and outlying rural areas," the commission added. "In short, there is the incalculable social cost of a diminished public confidence in governmental activities."

Noteworthy is the fact that so many academic Iowans have taken leading roles in the state's comprehensive planning studies over the years. Head of the new "Iowa 2000" is President Willard Boyd of the University of Iowa. And Bowen was involved in the planning research of the 1930 s as well as serving as head of the 1958 commission.

P. H. Elwood, then Iowa State's architecture chief, was a key official in both the planning board and the 1944 postwar commission. Dean Kildee of Iowa State headed the planning board. Experts from the colleges greatly assisted in the twenty-five-year 
plan research and recommendations of 1933.

Prior to the twenty-five-year plan there appeared "The Book of Iowa," a 1932 survey of Iowa's agricultural, industrial and natural resources. The survey emphasized what Iowa had at the time, rather than predicting what was to come in the future: Head of that project was Anson Marston, Dean of Engineering at lowa State.

Some of the observations in the past planning efforts are as applicable today as they were long years ago. J. N. (Ding) Darling's plea for beauty in a city is a case in point. In the 1935 planning board report on Des Moines housing, he wrote:

More of a city's prosperity depends on its beauty than is commonly accepted. . A municipality which is not inviting to the visitor, and which sends him away cold, soon becomes a community of citizens trying fruitlessly to get rich taking in each others' washing.

Beauty spots that linger in the memory are more the result of wise planning than of extravagant expenditure. That city will fare ill which leaves in the mind of the visitor within its gates nothing but an impression of factory chimneys, crowded tenements and blighted residential districts.

It is equally true that a city whose guests are eager to come again, and who leave with regret, will not only be rewarded by their repeated patronage but will be equally attractive to those who make their homes within its pleasing environs. . . 
Copyright of Annals of Iowa is the property of State of Iowa, by \& through the State Historical Society of Iowa and its content may not be copied or emailed to multiple sites or posted to a listserv without the copyright holder's express written permission. However, users may print, download, or email articles for individual use. 